J. Perinat. Med. 15 (1987) 447

\title{
New approaches to hormonal acceleration of fetal lung maturation
}

\author{
Jean-Claude Schellenberg and Graham C. Liggins \\ Postgraduate School of Obstetrics and Gynecology, National Women's Hospital, \\ Auckland, New Zealand
}

\section{Introduction}

Administration of glucocorticoids to women at risk of preterm delivery for the prevention of neonatal respiratory distress syndrome (RDS) has become a routine treatment in many obstetrical centers. In the quest for more efficient methods to accelerate lung maturation in the fetus a number of compounds have been investigated in experimental animals [2]. Thyroid hormones [1, 12, 33, 44], bromhexine metabolite VIII (ambroxol) [41, 48], carnitine [40] and thyrotropin stimulating hormone (TRH, LIGGINS unpublished) have recently also been used in humans.

In this paper we will review the effects on lung maturation of glucocorticoids and report recent relevant findings from our laboratory.

\section{Glucocorticoids}

\subsection{Experimental data}

Experiments in vitro and in vivo in several species including humans have shown that glucocorticoids stimulate the synthesis and secretion of pulmonary surfactant, promote morphological development of the lung and enhance survival of prematurely born fetuses $[13,15,18,22,23,34]$. Glucocorticoid receptors have been demonstrated in lung tissue and in cultures enriched in adult or fetal alveolar type II cells [7, 16]. A number of direct and indirect mechanisms of glucocorticoid action has been proposed:

1 - Increase in surfactant synthesis through enzyme induction [38],

2- Increase in surfactant secretion (through $3, ?$ ) $[13,19,36]$,

\section{Curriculum vitae}

Jean-Claude SchellenBERG, M.D., Specialist in Obstetrics and Gynaecology (FMH), Diplomate of the American Board of Anesthesiology, MRCOG, MRNZCOG. Resident in Surgery and Obstetrics Lachen, Switzerland 1971. Resident and Consultant in Obstetrics and Gynaecology, University Hospital

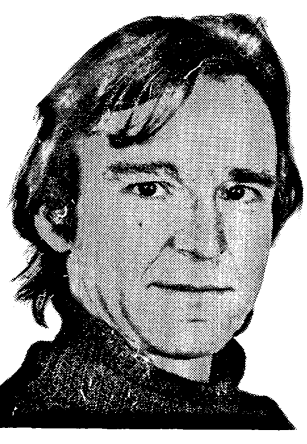
Lausanne, Switzerland 1972-1977. Resident in Anesthesiology, Massachusetts General Hospital, Boston, USA 1977-1979. Consultant in Anaesthesia, University Hospital, Basel, Switzerland 1979-1981. Research fellow with Professor LigGins since 1981. Ph D. thesis on fetal lung maturation. Temporary Senior Lecturer in Obstetrics and Gynecology, University of Auckland, New Zealand.

3 - Induction of pulmonary $\beta$-adrenergic receptors $[9,31]$,

4- Stimulation of production of fibroblast pneumonocyte factor $[14,37]$,

5 - Increase in plasma levels of triiodothyronine (in part through 6) [47],

6 - Conversion of thyroxine to triiodothyronine [47],

7- Induction of conversion of noradrenaline to adrenaline [32],

8- Stimulation of glycogenolysis [17].

Lung maturation at term fails to occur in sheep hypophysectomized at 110 days gestation [26]. While infusion of ACTH at term increases distensibility and stability of the lungs in hypophysec- 
tomized fetuses, infusion of cortisol is ineffective [26]. Conversely, infusion of ACTH at term to fetal sheep adrenalectomized at 100 days gestation fails to accelerate lung maturation whereas infusion of cortisol increases distensibility of the lung although stability of the lung and alveolar surfactant levels are not increased [27]. This suggests that cortisol and at least one other factor are required for lung maturation in sheep and that structural changes (rather than surfactant alone) contribute to changes in distensibility.

\subsection{Clincial data}

Although it is well established that antenatal glucocorticoid treatment reduces the incidence and severity of RDS in prematurely born infants it is also evident that a significant number of fetuses do not respond to the treatment $[4,8,10,21,25$, $35,45,50]$. This is of particular consequence in very immature fetuses which have been found by some authors not to respond to glucocorticoids $[4,10,50]$. In the Auckland trial, the incidence of RDS was lower in treated males of less than 30 weeks gestation than in controls $(21 \%$ versus $61 \%, \mathrm{p}<0.015$ ) but not in females [20]. The study of BALLARD et al suggested that the incidence of RDS is significantly reduced by betamethasone treatment in infants of about 27 to 30 weeks of gestation (birth weight between $751 \mathrm{~g}$ and $1250 \mathrm{~g}$ ), but that smaller and larger infants do not benefit from the treatment [4]. In a retrospective controlled study on 678 infants with a mean birthweight of $1100 \mathrm{~g}$ and a mean gestational age of 28.5 weeks, perinatal mortality was nearly halved and body weight and head circumference were greater at two years of age in treated infants than in controls [11].

When $24 \mathrm{mg}$ of betamethasone is administered intramuscularly either in two divided doses $12 \mathrm{~h}$ apart or in four divided doses 12 hourly, levels of fetal glucocorticoid activity are in the range of those in newborns with RDS or with prolonged premature rupture of the membranes $[5,6]$. It is therefore unlikely that these regimens produce teratogenic effects $[3,5]$. Extensive physical, psycho-motor, general medical, neurological, pulmonary and immunological testing of infants treated antenatally with glucocorticoids have confirmed that child development is unlikely to be affected by antenatal glucocorticoid prophylaxis $[20,24,29,30,49]$.

\section{Synergistic hormonal effects}

\subsection{Experiments in fetal sheep}

In fetal sheep, infusion of cortisol at around 125 days gestation (term is 147 days) produces only a small increase in pulmonary distensibility [43] or has no detectable effect on lung maturation [28]. Although combined infusion of cortisol + triiodothyronine or cortisol + adrenaline or cortisol + triiodothyronine + prolactin increase alveolar surfactant, only a combination of cortisol + triiodothyronine + prolactin increases distensibility of the lung above values obtained with infusion of cortisol alone [43]. This suggests that

- there is synergism on alveolar surfactant production between cortisol and triiodothyronine and between cortisol and adrenaline,

- there is synergism between cortisol, triiodothyronine and prolactin in increasing distensibility of the lung, and

- distensibility of the lung does not depend on surfactant levels alone.

Elastin and collagen concentration were higher in lungs that were distensible and stable after hormone infusion than in non-distensible and unstable lungs, suggesting that changes in connective tissue are associated with changes in the mechanical properties of the fetal lung [42].

Similar results were obtained in fetal sheep infused with TRH between Days 121 and 128 of gestation. Infusion of TRH, which increases ovine fetal plasma levels of triiodothyronine and prolactin [46], does not increase distensibility and stability of the ovine fetal lung, whereas combined infusion of TRH + cortisol produces distensible and stable lungs [28].

\subsection{Possible clinical applications}

In humans, TRH crosses the placenta and produces a rise in fetal plasma triiodothyronine [39]. As in sheep, there appears to be refractoriness of the human lung to glucocorticoids at an early gestational age $[4,10,20,50]$. Given the excellent response of the sheep fetus to combined treatment with TRH and cortisol at a gestational age when the response to cortisol alone is negligible [28], administration of $\mathrm{TRH}+$ betamethasone to women at risk of very premature birth may be more efficient than treatment with betamethasone alone. The validity of this speculation is currently being tested in our institution by a controlled, double-blind clinical trial. 


\section{Conclusion}

Although the efficacy of antenatal glucocorticoid therapy for the propylaxis of RDS is well established it is also true that many fetuses, particularly of low gestational age, do not respond to the treatment. Multihormonal treatment accelerates lung maturation in sheep at an early gestational age when infusion of cortisol alone is ineffective. It remains to be seen whether such therapy is effective in the human fetus.

\section{Summary}

The paper reviews the effects on lung maturation of glucocorticoids in animals and humans and presents relevant recent findings from the author's laboratory. It is now well established that antenatal glucocorticoid treatment reduces the incidence and severity of the respiratory distress syndrome (RDS) in prematurely born infants. The recommended doses of glucocorticoids produce fetal glucocorticoid activity levels similar to those of newborns with RDS or prolonged rupture of the membranes. Extensive follow-up studies have shown that adverse effects on child development are unlikely to occur. It is also evident that a significant number of fetuses do not respond to the treatment, which is of particular consequence in fetuses of less than 28 weeks

gestation. These fetuses are less likely to respond to glucocorticoid therapy than fetuses between 28 and 32 weeks gestation and are at a higher risk of developing complications due to their immaturity. In fetal sheep, there is a similar decrease in the efficacy of glucocorticoids on lung maturation with decreasing gestational age. Simultaneous infusion of cortisol, triiodothyronine and prolactin but not of any of these hormones administered singly or in combination of two produced mature lungs in fetal sheep of 125 days gestation. Similar results were obtained with thyrotropin releasing hormone (TRH) and cortisol. It remains to be seen whether the combined administration of glucocorticoids and TRH accelerates lung maturation in human fetuses.

Keywords: Fetal organ maturity, follow-up studies, glucocorticoids, lung, prolactin, respiratory distress syndromeprevention, sheep, thyrotropin releasing hormone, triiodothyronine.

\section{Zusammenfassung}

\section{Neue Möglichkeiten zur hormonellen Induktion der feta-} len Lungenreifung

Die vorliegende Arbeit liefert eine Übersicht zum Thema der Beeinflussung der Lungenreifung durch Glukokortikoide bei Menschen und Tieren. Darüber hinaus werden neuere Ergebnisse aus Versuchsreihen, die von den Autoren durchgeführt werden, mitgeteilt. Es gilt als gesichert, $\mathrm{da} ß$ eine antenatale Glukokortikoidbehandlung die Inzidenz und den Schweregrad eines Atemnotsyndroms (RDS) bei Frühgeborenen reduziert. Die empfohlene Glukokortikoiddosis erzeugt eine Kortikoidaktivität beim Feten, wie sie auch bei Neugeborenen mit RDS oder nach vorzeitigem Blasensprung gefunden wird. Ausgedehnte Nachuntersuchungen haben gezeigt, daß unerwünschte Effekte bei der kindlichen Entwicklung sehr unwahrscheinlich sind. Offensichtlich spricht aber eine beträchtliche Anzahl von Feten nicht auf die Be- handlung an. Dies ist besonders bedeutungsvoll für $\mathrm{Fe}$ ten unterhalb der 28. Schwangerschaftswoche, da diese in geringerem Maße auf die Kortikoidtherapie ansprechen als Feten zwischen der 28. und 32. Woche und eher in Schwierigkeiten geraten infolge ihrer Unreife. Beim Schaffeten sind die Glukokortikoide ebenfalls mit abnehmendem Gestationsalter weniger wirksam. Die gleichzeitige Infusion von Kortisol, Trijodthyronin und Prolaktin führte zu reifen Lungen bei Schaffeten mit 125 Tagen Gestationsdauer. Dies gilt nicht, wenn die Substanzen einzeln oder als Zweierkombination verabreicht wurden. Bei Verwendung von Thyrotropin-Releasing-Hormon (TRH) und Kortisol wurden vergleichbare Ergebnisse erzielt. Es bleibt nachzuweisen, ob auch bei menschlichen Feten die kombinierte Gabe von TRH und Glukokortikoiden die Lungenreifung beschleunigt.

Schlüsselwörter: Fetale Organreifung, Nachuntersuchungen, Glukokortikoide, Lunge, Prävention eines RDS, Prolaktin, Schaf, Thyrotropin-Releasing-Hormon, Trijodthyronin.

\section{Résumé}

Nouvelles approches concernant l'accéleration hormonale de la maturation pulonaire fretale

Cet article passe en revue les effets sur la maturation pulmonaire des glucocorticoïdes chez l'animal et chez l'homme et présente des données récentes sur le sujet provenant du laboratoire des auteurs. Il est bien établi que le traitement par glucocorticoïdes anténatal diminue l'incidence et la sévérité du syndrome de détresse respiratoire (SDR) chez les enfants nés prématurément. Les doses recommandées de glucocorticoïdes produisent des 
taux plasmatiques d'activité glucocorticoïde semblables aux taux mesurés chez les nouveaux-nés atteints de SDR et d'enfants nés après rupture prolongée des membranes. Des études de contrôle ont demontré qu'il est peu probable que le traitement ait des effets secondaires sur le développement de l'enfant. Il est aussi vrai que cette thérapie est inefficace dans un bon nombre de cas. Ceci est d'une importance capitale chez le fœtus de moins de 28 semaines de gestation. Celui-ci est particulièrement disposé à des complications dues à l'immaturité et répond moins bien aux glucocorticoïdes que le foetus entre 28 and 32 semaines. Chez le fœtus du mouton l'effet des glucocorticoïdes sur la maturation pulmonaire diminue de façon semblable avec un âge de gestation décroissant. Des perfusions de cortisol, de triiodothyronine et de prolactine administrées simultanément produisent des poumons matures dans le fœtus de mouton de 125 jours de gestation; cela ne se produit pas si une seule de ces hormones est administrée ou si deux d'entre elles seulement sont combinées. Des résultats similaires ont été obtenus avec de la thyrotropin releasing hormone (TRH) et du cortisol. Il reste à voir si l'administration combinée de glucocorticoïdes et de TRH accélère la maturation pulmonaire chez les fætus humains.

Mots-clés: Etudes de surveillance, glucocorticoïdes, maturité des organes fœtaux, mouton, poumon, prolactine, syndrome de détresse respiratoire-prévention, thyrotropin releasing hormone, triiodothyronine.

\section{References}

[1] Amato M, D Sidiropoulos, G von Muralt: Preventione della malattia delle membrane ialine mediante somministrazione intraamniotica di tiroxina. Pediatr Med Chir 6 (1984) 363

[2] Ballard PL: Hormonal Aspects of fetal lung development. In: FARRELL PM (ed): Lung Development: Biological and Clinical Perspectives, Vol. II. Neonatal Respiratory Distress. Academic Press, New York 1982

[3] Ballard RA, PL Ballard: Use of glucocorticoid therapy to prevent respiratory distress syndrome. A supporting view. Am J Dis Child 130 (1976) 982

[4] Ballard RA, PL Ballard, S Sniderman: Prenatal administration of betamethasone for prevention of respiratory distress syndrome. J Pediatr 94 (1979) 97

[5] Ballard PL, P Granberg, RA Ballard: Glucocorticoid levels in maternal and cord serum after prenatal betamethasone therapy to prevent respiratory distress syndrome. J Clin Invest 56 (1975) 1548

[6] Ballard PL, GC Liggins: Glucocorticoid activity in cord serum: Comparison of hydrocortisone and betamethasone regimes. J Pediatr 101 (1982) 468

[7] Ballard PL, RJ Mason, WHI Douglas: Glucocorticoid binding by isolated lung cells. Endocrinology 102 (1978) 1570

[8] BLOCK MF, OR KLING, WM Crosby: Antenatal glucocorticoid therapy for the prevention of respiratory distress syndrome in the premature infant. Obstet Gynecol 50 (1977) 186

[9] Cheng JB, A Goldfien, PL Ballard, JM RoBERTS: Glucocorticoids increase pulmonary betaadrenergic receptors in fetal rabbit. Endocrinology 107 (1980) 1646

[10] Collaborative Group on Antenatal Steroid THERAPY: Effect of antenatal dexamethasone administration on the prevention of respiratory distress syndrome. Am J Obstet Gynecol 141 (1981) 276
[11] Doyle LW, WH Kitchen, GW Ford, AL RickARDS, JV LISSENDEN, MM RYAN: Effects of antenatal steroid therapy on mortality and morbidity in very low birth weight infants. J Pediatr 108 (1986) 287

[12] Dudenhausen W: Wirkungen der intraamnialen Thyroxingabe auf den Feten. Geburtshilfe Frauenheilkd 44 (1984) 777

[13] EKELUNd L, G ENHORNING: Glucocorticoids and beta-adrenergic-receptor agonists: their combined effect on fetal rabbit lung surfactant. Am J Obstet Gynecol 152 (1985) 1063

[14] Floros J, M Post, BT Smith: Glucocorticoids affect the synthesis of pulmonary fibroblast-pneumonocyte factor at a pretranslational level. J Biol Chem 260 (1985) 2265

[15] Funkhouser JD, ER Hughes: Fetal lung disaturated phosphatidylcholine. Ostensible increase following exposure to dexamethasone. Biochim Biophys Acta 619 (1980) 506

[16] Giannopoulos G: Variations in the levels of cytoplasmic glucocorticoid receptors in lungs of various species at different developmental stages. Endocrinology 94 (1974) 450

[17] Gilden C, A Sevanian, DF Tierney, SA Kaplan, CT BARRETT: Regulation of fetal lung phosphatidyl choline synthesis by cortisol: role of glycogen and glucose. Pediatr Res 11 (1977) 845

[18] Gonzales LW, PL Ballard, R Ertsey, MC WilliAMS: Glucocorticoids and thyroid hormones stimulate biochemical and morphological differentiation of human fetal lung in organ culture. J Clin Endocrinol Metab 62 (1986) 678

[19] Hallman M, K Teramo, S Sipinen, K Raivio: Effects of betamethasone and ritordrine on the fetal secretion of lung surfactant. J Perinat Med 13 (1985) 23

[20] HowIE RN: Pharmacological acceleration of lung maturation. In: RaIvio KO, N Hallman, K KoUVAlaINen, I VALIMAKI (eds): Respiratory Distress Syndrome. Academic Press, London 1984 
[21] HowIE RN, GC Liggins: The New Zealand study of antepartum Glucocorticoid treatment. In: FARRELL PM (ed): Lung Development: Biological and Clinical Perspectives / II. Neonatal Respiratory Distress Syndrome. Academic Press, New York 1982

[22] Kessler DL, WE Truog, JH Murphy, S Palmer, TA STANDAERT, DE WOODRUM, WA Hodoson: Experimental hyaline membrane disease in the premature monkey. Effects of antenatal dexamethasone. Am Rev Respir Dis 126 (1982) 62

[23] KikKawa Y, M Kaibara, EK Motoyama, MM ORZALESI, CD COOK: Morphologic development of fetal rabbit lung and its acceleration with cortisol. Am J Pathol 64 (1971) 412

[24] Kouvailainen K, M Kiovisto, T Nurmi, AL SAUKKONEN, M UHARI: Potential risks of glucocorticoid prophylaxis of RDS. In: RaIVIO KO, N Hallman, K Kouvalainen, I Valimaki (eds): Respiratory Distress Syndrome. Academic Press, London 1984

[25] LigGINS GC, RN HowIE: A controlled trial of antepartum glucocorticoid treatment for prevention of the respiratory distress syndrome in premature infants. Pediatrics 50 (1972) 514

[26] Liggins GC, JA Kitterman, GA Campos, JA Clements, CS Forster, CH Lee, RK Creasy: Pulmonary maturation in the hypophysectomised ovine fetus. Differential responses to adrenocorticotrophin and cortisol. J Dev Physiol 3 (1981) 2

[27] Liggins GC, JC SChellenberg, K Finberg, JA KitTerman, CH LeE: The effects of $\mathrm{ACTH}_{1-24}$ or cortisol on pulmonary maturation in the adrenalectomized ovine fetus. J Dev Physiol 7 (1985) 105

[28] Liggins GC, JC Schellenberg, M Manzai, DJ CoURT: Synergistic effects of thyrotropin releasing hormone (TRH) and cortisol on lung maturation in the ovine fetus. Proc Endoc Soc Aust 28 [Suppl 2] (1985) 32

[29] MacArthur BA, RN Howie, JA Dezoete, J ElKINS: Cognitive and psychosocial development of 3-year-old children whose mothers were treated antenatally with betamethasone. Pediatrics 68 (1982) 638

[30] MacArthur BA, RN Howie, JA Dezoete, J ElKINS: School progress and cognitive development of 6-year-old children whose mothers were treated antenatally with betamethasone. Pediatrics 70 (1982) 99

[31] Maniscalco WM, DL Shapiro: Effects of dexamethasone on beta-adrenergic receptors in fetal lung explants. Pediatr Res 17 (1983) 274

[32] Margolis FL, J Roffi, A Jost: Norepinephrine methylation in fetal rat adrenals. Science 154 (1966) 275

[33] Mashiach S, G Barkai, J Sack, E Stern, B GoldMAN, N BRISH, DM SERR: Enhancement of fetal lung maturity by intra-amniotic administration of thyroid hormone. Am J Obstet Gynecol 130 (1978) 289
[34] MENDELSON CR, JM SNYDER: Effect of cortisol on the synthesis of lamellar body glycerophospholipids in fetal rabbit lung in vitro. Biochim Biophys Acta 834 (1985) 85

[35] Papageorgiou AN, MF Desgranges, M Masson, E Colle, R Shatz, MM Gelfand: The antenatal use of betamethasone in the prevention of respiratory distress syndrome: A controlled double blind study. Pediatrics 63 (1979) 73

[36] Platzker ACG, JA Kitterman, RJ Mescher, JA Clements, WH Tooley: Surfactant in the lung and tracheal fluid of the fetal lamb and acceleration of its appearance by dexamethasone. Pediatrics 56 (1975) 554

[37] Post M, BT SMITH: Effect of fibroblast-pneumonocyte-factor on the synthesis of surfactant phospholipids in type II cells from fetal rat lung. Biochim Biophys Acta 793 (1984) 297

[38] RoonEy SA: Lung surfactant. Environ Health Perspect 55 (1984) 205

[39] Roti E, A Gnudi, LE Braverman, G Robuschi, R Emanuele, P Bandini, L Benassi, A Pagliani, CH EMERSON: Human cord blood concentrations of thyrotropin, thyroglobulin, and iodothyronines after maternal administration of thyrotropin-releasing hormone. J Clin Endocrinol Metab 53 (1981) 813

[40] SAlzer H, A Lohniger, P Sevelda, E Legenstein: Carnitine for the stimulation of fetal lung maturation. Clinical case report. Gynaekol Rundsch 25 (1985) 72

[41] Salzer H, H Weidinger, G Simbruner, E VytiskaBIRNSDORFER: Ambroxol versus Betamethason zur Förderung der antepartalen Lungenreife - eine multizentrische Studie. Z Geburtshilfe Perinatol 190 (1986) 49

[42] SCHELLENBERG JC, GC Liggins: Elastin and collagen in the fetal sheep. II. Relationship to mechanical properties of the lung. Pediatr Res 22 (1987) 339

[43] Schellenberg JC, GC Liggins, M Manzar: Synergistic effects of cortisol, tri-iodothyronine, prolactin and adrenaline on lung maturation in the ovine fetus. Proc Endocr Soc Aust 28 [Suppl 2] (1985) 33

[44] Schreyer P, E Caspi, Y LetKo, R Ron-El, N PINTo, JL ZeIDMAN: Intraamniotic triiodothyronine instillation for prevention of respiratory distress syndrome in pregnancies complicated by hypertension. J Perinat Med 10 (1982) 27

[45] Taeusch, HW, F Frigoletto, J Kitzmiller, ME Avery, A Hehre, B Fromm, E Lawson, RK NefF: Risk of resiratory distress syndrome after prenatal dexamethasone treatment. Pediatrics 63 (1979) 64

[46] Thomas AL, PMB Jack, JG Minns, PW NathanIELSZ: Effect of synthetic thyrotrophin releasing hormone on thyrotrophin and prolactin concentrations in the peripheral plasma of the pregant ewe, lamb fetus and neonatal lamb. Biol Neonate 26 (1985) 109 
[47] Thomas AL, EJ Krane, PW Nathanielsz: Changes in the fetal thyroid axis after induction of premature parturition by low dose continuous intravascular cortisol infusion to the fetal sheep at 130 days of gestation. Endocrinology 103 (1978) 17

[48] Wauer RR, G Schmalisch, K Menzel, M SchroDer, K Muller, R Tiller, G Methfessel, U SitKa, E Koepke, C Plath, C Schlegel, M Bottcher, I KOPPE, U FrICKE, K SEVERIN, R JACOBI, W SCHMID, GK Hinkel, I Nitz, D KunZe, G Reichman, B LACHMANN, K LAMPE, EL GRAUEL: The antenatal use of ambroxol (bromhexine metabolite VIII) to prevent hyaline membrane disease: A controlled double-blind study. Biol Res Pregnancy Perinatol 3 (1982) 84
[49] Wong YC, CS Beardsmore, M Silverman: Antenatal dexamethasone and subsequent lung growth. Arch Dis Child 57 (1982) 536

[50] Young BK, SA KLeIN, M Katz, SJ Wilson, GW DougLAS: Intravenous dexamethasone for prevention of neonatal respiratory distress: A prospective controlled study. Am J Obstet Gynecol 138 (1980) 203

Dr. med. Jean-Claude Schellenberg

Postgraduate School of Obstetrics and Gynaecology National Women's Hospital

Claude Road

Auckland 3, New Zealand 